The Australian Economic Review, vol. 41, no. 2, pp. 141-59

\title{
How and Why Has Teacher Quality Changed in Australia?
}

\author{
Andrew Leigh and Chris Ryan* \\ Research School of Social Sciences, The Australian National University
}

\begin{abstract}
International research suggests that differences in teacher performance can explain a large portion of student achievement. Yet little is known about how the quality of the Australian teaching profession has changed over time. Using consistent data on the academic aptitude of new teachers, we compare those who have entered the teaching profession in Australia over the past two decades. We find that the aptitude of new teachers has fallen considerably. Between 1983 and 2003, the average percentile rank of those entering teacher education fell from 74 to 61 , while the average rank of new teachers fell from 70 to 62 . We find that two factors account for much of the decline: a fall in average teacher pay (relative to other occupations) and a rise in pay differentials in non-teaching occupations.
\end{abstract}

\footnotetext{
* This paper was originally prepared as a report for the Australian Department of Education, Science and Training. The views expressed are those of the authors and do not represent the views of the Department of Education, Science and Training. We are grateful for feedback on an earlier draft from officers of the Department, participants at a seminar at the Australian National University, Mark Wooden and two anonymous referees. Elena Varganova provided outstanding research assistance. In revising the paper for publication, Leigh also acknowledges support under the Australian Research Council's Discovery funding scheme (project number DP0665260).
}

\section{Introduction}

Teacher quality has been shown to be an important input into the education production function. There is therefore substantial concern at the prospect that teacher quality may have fallen over recent decades. In this paper, we test this hypothesis using data from Australia. Using panel surveys that test individuals' literacy and numeracy in high school and then follow them to see which career they choose, we are able to estimate how the academic aptitude of those entering the teaching profession has changed over time.

Having estimated changes in the academic aptitude of new teachers, which we will tend to refer to more broadly as 'teacher quality', we then set about investigating the role that salary has played in these changes. We focus on three aspects of pay: the returns to aptitude in teaching; average teacher pay; and pay dispersion in non-teaching occupations. Using data from several sources, we investigate the effect of these changes on the quality of the teaching workforce.

Understanding how teacher aptitude has changed over time is an interesting question merely from the perspective of the labour market. According to the recent data, 264919 Australians are school teachers, most on a fulltime basis. ${ }^{1}$ This makes teachers one of the largest occupations in the nation, accounting for 2.7 per cent of all employees. It is inherently useful to see how the career decisions of such a large occupation have changed over time.

But teacher quality also matters from the perspective of students. Studies from Australia and the United States have shown that the performance gap between the best and worst teachers is substantial. Using panel data from

\footnotetext{
(C) 2008 The University of Melbourne, Melbourne Institute of Applied Economic and Social Research
} Published by Blackwell Publishing Asia Pty Ltd 
Queensland, with teacher and student fixed effects, Leigh (2007) finds that moving up one standard deviation on the teacher quality distribution is associated with a gain in student achievement of approximately 0.1 standard deviations. (A similar degree of dispersion has been observed across US teachers: Rockoff 2004; Rivkin, Hanushek and Kain 2005.) This suggests that switching from a teacher at the 10th percentile to a teacher at the 90th percentile would raise a student from the median to the 60th percentile. ${ }^{2}$

To preview our results, we find that the academic aptitude of those entering teaching has fallen over the past 20 years. Exploring our various hypotheses, we find that declining average teacher pay and rising pay dispersion in nonteaching occupations both played a significant role in the decline in the academic aptitude of new teachers.

The remainder of this paper is structured as follows. Section 2 reviews the previous literature. Section 3 outlines the general trends in teacher aptitude in Australia. To better understand the reasons for these changes, Section 4 then presents data on trends in teacher and nonteacher pay over the past quarter century. In more formal analysis, we set out a simple model of occupational choice in Section 5 and use this model to econometrically analyse teacher quality trends in Section 6. The final section concludes.

\section{Previous Literature}

\subsection{Trends in Teacher Aptitude}

In the United States, several recent studies have shown that the academic aptitude of those who enter teaching in the United States has fallen over recent decades. Corcoran, Evans and Schwab (2004a, 2004b) combine several longitudinal surveys and find that from the early 1970 s to 2000 , the percentile rank of the mean female teacher on standardised achievement tests fell from 65 to $46 .^{3}$ The decline took place steadily over the three decades and was largely driven by a fall in the fraction of women in the top two deciles entering teaching. Evi- dence from the National Longitudinal Surveys of Youth (Murnane et al. 1991; Bacolod 2003) and the ACT exam (Leigh and Mead 2005) support this conclusion. Corcoran, Evans and Schwab (2004b) also analyse male teachers and observe no corresponding decline, though because most teachers are female, their estimates for men are less precise.

In the United Kingdom, Nickell and Quintini (2002) compare the aptitude scores (measured at ages 11-16) of those who became teachers in the 1970s and 1990s. They find no significant change in the aptitude of new female teachers, but an 11-13 percentage point drop in the aptitude of new male teachers. As in Australia, about 75 per cent of UK teachers are women, so when the results for men and women are combined, there appears to have been little change in the academic aptitude of the typical new teacher in the United Kingdom.

In Australia, a substantial literature exists on pedagogy and professional standards in teaching (for a recent review, see Watson 2005). However, little work has been done on the academic standards of those entering teaching, though the relatively low rank of those entering teacher education courses has occasionally been noted. For example, one government report (HED, DEET 1990) noted that 3 per cent of those commencing teacher education courses in 1989 were in the top quartile of all university entrants, while 54 per cent were in the bottom quartile. Analysis in the report of the Committee for the Review of Teaching and Teacher Education (2003, Table 14) found that 14.8 per cent of those in teacher education courses were from the top achievement group in terms of year 9 school performance (those at least one standard deviation above the average performance level), compared with 27.2 per cent of those enrolled in other university courses. However, because not all those in teacher education courses go on to become teachers, these studies are not necessarily an accurate reflection of the ability distribution of new teachers. Such studies are also typically limited to a single snapshot-we are not aware of any study that has analysed the changing

(C) 2008 The University of Melbourne, Melbourne Institute of Applied Economic and Social Research 
ability distribution of Australian teachers over time.

\subsection{Factors Affecting Teacher Aptitude}

What might have caused the decline in teacher aptitude observed in the United States over recent decades? Corcoran, Evans and Schwab (2004b) stress the role of women entering non-teaching professions. They show that in the 1960s, 49 per cent of female university graduates were teachers. By the 1990s, female university graduates were more likely to be in management (14 per cent) or clerical work (17 per cent) than in teaching (12 per cent). Using cross-state variation, Hoxby and Leigh (2004) formally test two hypotheses-changing gender pay gaps in alternative occupations and union-induced pay compression. They find that the rise in salaries of high-ability women in alternative occupations explains about one-quarter of the teacher quality decline, while approximately threequarters was due to pay compression in teaching.

More generally, a literature exists on the relationship between teacher pay and teacher quality (for a review, see Hanushek and Rivkin 2006). In the United States, Ballou and Podgursky (1995, 1997) present simulations showing that since teaching labour markets are typically in a state of excess supply, raising (or, presumably, lowering) average teacher pay would have a small effect at best on the SAT scores of prospective teachers. By contrast, Figlio (1997) exploits cross-sectional variation in average salaries across school districts at a single point in time and finds that school districts with higher teacher salaries tend to attract more teachers from selective universities and with subject matter qualifications. For Australia, Leigh (2006) uses state panel data, instrumenting for teacher pay using uniform salary schedules. He finds that a 1 per cent rise in average teacher pay boosts the test scores of those entering teacher education courses by 0.6 percentage points. ${ }^{4}$ Other studies find a positive relationship between teacher salaries and student outcomes, ${ }^{5}$ and between teacher pay and teacher retention. ${ }^{6}$

\section{Trends in Teacher Quality in Australia}

In measuring teacher quality, one would ideally want a broad metric which captured the ability of teachers to raise student performance on tests, as well as on material regarded as important but difficult to test, such as social skills. ${ }^{7} \mathrm{~A}$ perfect teacher quality metric might also encapsulate the ability of a good teacher to work well with other teachers and school administrators and to raise their performance in the classroom.

Unfortunately, since such a measure of teacher quality is not available over the period in question, we opt instead to use a narrower metric - the literacy and numeracy performance of teachers in standardised tests while they were themselves at school. There are three limitations to using these tests as a measure of academic aptitude. First, such tests are measured with error and students' results may be subject to random factors (for example, the classic barking dog outside the classroom). Our approach assumes that these random factors were uncorrelated with whether or not students went on to become teachers. Second, literacy and numeracy tests do not take into account a broader range of subject skills, such as computing and science. To the extent that these skills are uncorrelated with literacy and numeracy, failing to test them induces error into our measure of academic aptitude. And third, our approach assumes that the aptitude of an individual teacher does not change over time. ${ }^{8}$ To the extent that individuals mature at different rates, this will also induce measurement error into our aptitude variable. These three sources of measurement error should be borne in mind when interpreting our results.

The use of teacher aptitude as a proxy for teacher quality has been validated in other studies, which have found a strong positive correlation between teachers' classroom performance and their own standardised test scores. This relationship appears to hold for teachers' scores in state teacher certification exams (Ferguson 1991; Ferguson and Ladd 1996), and for teachers' exams when they were in high school (Ehrenberg and Brewer 1994). Comparing various predictors of teacher quality, Ehrenberg and Brewer (1994) conclude that 
a teacher's own test scores and the selectivity of the college that the teacher attended are both positively related to pupil achievement, with the teacher's test scores having the stronger effect. ${ }^{9}$ Another possible validation of the use of test scores as a proxy for teacher effectiveness is the evidence (discussed below) that, in non-teaching occupations, people with higher test scores tend to earn higher wages; this indicates that teenage test scores are valued by the general labour market.

To measure teacher aptitude, we use the data from six Longitudinal Surveys of Australian Youth (LSAY) cohorts. These cohorts are the Youth in Transition 1961, 1965, 1970 and 1975 birth cohorts (YIT 61, YIT 65, YIT 70 and YIT 75) and the Longitudinal Surveys of Australian Youth 1995 and 1998 Year 9 cohorts (LSAY 95 and LSAY 98). These surveys have the advantage that they contain information on literacy and numeracy tests, university course choices and career choices. While some institutional features of teacher education have changed over this period (incorporation into universities, lengthening of courses and the move to specialised secondary teaching degrees, rather than general degrees followed by graduate teaching diplomas, as the typical course taken by secondary teachers), the data and our approach of measuring course and career choices over a number of years allow us to deal with these changes. YIT 61 did not capture teacher education students in relevant years, while LSAY 98 were too young in available data to have been observed working as a teacher. Excluding these, the average number of teacher education students in each sample is 184 , while the average number of teachers in each sample is 141. To account for sample attrition-which is relatively high in the $\mathrm{LSAY}^{10}$ — we re-weight each sample to match the original gender by achievement distribution (our main results are not sensitive to the particular weighting system). More information on the data is provided in Leigh and Ryan (2006, Appendix I).

In most cases, standardised tests were administered at age 14 or in year $9 .^{11,12}$ Respondents were then followed through their post-school education and into their working lives. In most cases, the cohorts were observed until at least
Figure 1 Ability Distribution of New Female Teachers

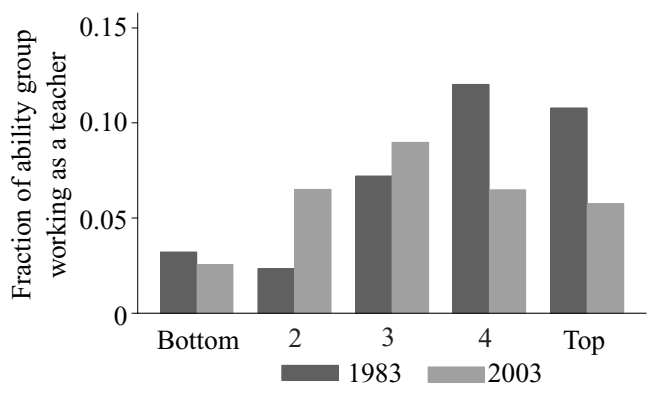

Source: Longitudinal Surveys of Australian Youth.

their mid-20s. Those in the first cohort sat the literacy and numeracy tests in 1975, and were observed as teachers around 1983. Those in the last cohort that graduated from university sat the tests in 1995 and were observed as teachers around 2003.

Although the literacy and numeracy tests taken by some of the LSAY cohorts were designed to be comparable across time, we opt to standardise them for each year. This is because our focus is on the career choices of the highest and lowest academic performers within each cohort. We then average each individual's scores in the literacy and numeracy tests and rank each cohort. ${ }^{13}$

Figure 1 shows the ability distribution of new female teachers in our first and last cohorts. We divide respondents into five achievement quintiles based on the average of their literacy and numeracy tests. The horizontal axis shows the year around which the cohort was observed in the labour force, while the vertical axis shows the fraction of people in each quintile who entered teaching. Over this 20-year period, the fraction of women in the top achievement quintile becoming teachers fell from 11 per cent to 6 per cent, while the fraction of women in the second-top achievement quintile fell from 12 per cent to 6 per cent. On average, we observe a substantial decline in the academic achievement of new female teachers. In 1983, the average woman entering teaching was at the 70th percentile of the achievement distribution. In 2003, the average woman entering teaching was at the 59th percentile of the achievement distribution. The change in the 
Figure 2 Ability Distribution of New Male Teachers

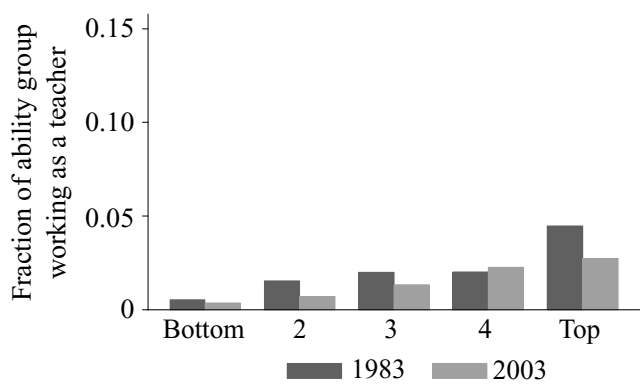

Source: Longitudinal Surveys of Australian Youth.

percentile rank of new female teachers between the first and last cohorts is statistically significant at the 1 per cent level.

Recall that Corcoran, Evans and Schwab (2004a, 2004b) found for the United States that the percentile rank of the mean female teacher on standardised achievement tests fell from 65 in the early 1970 s to 46 in 2000 . Assuming that the decline in both countries was constant over time, this suggests that the teacher quality drop has been a little smaller in Australia than in the United States and that the average academic aptitude of Australian teachers today is higher than their US counterparts.

Figure 2 shows the results for men. As with women, we observe a drop in the fraction of men in the top achievement quintile becoming teachers (from 4 per cent to 3 per cent). However, we do not observe any significant change in the fraction becoming teachers from the second-top achievement quintile. Moreover, the share of men becoming teachers from the lowest three achievement quintiles fell over this period. On average, we observe a slight rise in the average achievement of men entering teaching. In 1983, the average man entering teaching was at the 71 st percentile of the achievement distribution. In 2003, the average man entering teaching was at the 74th percentile of the achievement distribution.

Overall, since three-quarters of teachers are women throughout our sample period, the substantial declines in teacher quality among women swamp the small rise among men. Combining both men and women, the average person entering teaching was at the
Figure 3 Ability Distribution of Female Teacher Education Students

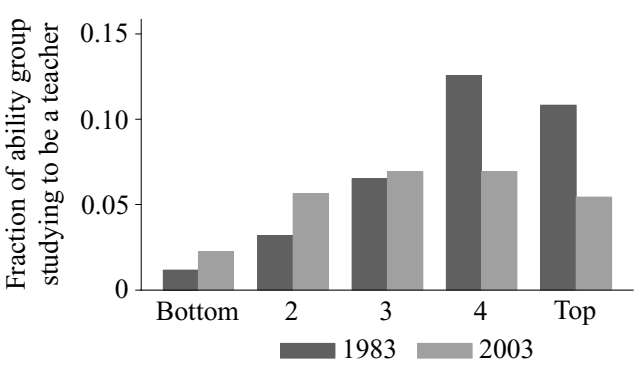

Source: Longitudinal Surveys of Australian Youth.

70th percentile of the achievement distribution in 1983, and at the 62nd percentile of the achievement distribution in 2003. The change in the percentile rank of new teachers between the cohorts is significant at the 1 per cent level.

In Figure 3, we focus on the ability distribution of women entering teacher education courses. This is a useful exercise, since it allows us to see whether the patterns observed among new female teachers are due to choices made at the beginning or the end of university. Among female teacher education students, we indeed see a similar pattern. From 1983 to 2003 , the fraction of women in the top achievement quintile studying to be teachers fell from 11 per cent to 5 per cent, while the fraction of women in the second-top achievement quintile fell from 13 per cent to 7 per cent. In 1983, the average woman studying to be a teacher was at the 72nd percentile of the achievement distribution. In 2003, the average woman studying teacher education was at the 60th percentile of the achievement distribution. The change in the percentile rank of females entering teaching courses between the cohorts is statistically significant at the 1 per cent level.

Figure 4 presents the same data for men entering teacher education. Unlike women, the ability distribution of men entering teacher education does seem to differ from the ability distribution of new male teachers. While the average ability of new male teachers rose slightly between 1983 and 2003, the average ability of men entering teacher education courses fell from 78 to 64 . Among women, we see little 
Figure 4 Ability Distribution of Male Teacher Education Students

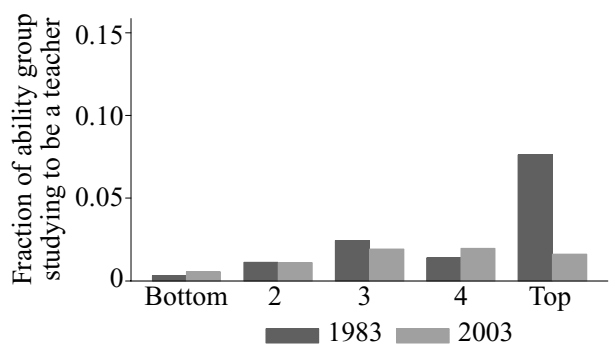

Source: Longitudinal Surveys of Australian Youth.

evidence that the individual's academic achievement affects the probability of proceeding from teacher education into teaching, but among men, those of lower academic ability appear to have been slightly less likely to proceed from teacher education into teaching. However, because the samples of men are smaller than those for women, the results are also less precise.

In analysing changes over time, Figures 1 to 4 use only the first and last cohorts. In Leigh and Ryan (2006), we also analyse the intervening LSAY cohorts, to see the pace of change. In the case of the top 20 per cent of the achievement distribution, we find that the decline is approximately uniform for women, while for men, a fall in the 1980s appears to have been followed by a slight rise in the 1990s. In the case of women in the bottom 50 per cent, there is a steady upwards trend in the share entering teaching, but no discernible trend for men in the bottom 50 per cent. In 1983, women in the top quintile were three times more likely to become teachers ( 11 per cent probability) than those in the bottom half ( 3 per cent probability). By 2003, the probabilities were the same for both groups (6 per cent probability among the top quintile, 5 per cent among the bottom half). Among those entering teacher education courses, the patterns appear similar.

Since women substantially outnumber men in teaching, it is reasonable to say that the general trends in the ability distribution of new teachers and the trends in the ability distribution of teacher education students mirror one another. This suggests that the ability of students entering teacher education courses is a valid proxy for the ability of new teachers. For example, in Leigh and Ryan (2006, Appendix II) we estimate the minimum entry standard for a Bachelor of Education at the University of Sydney over the period 1977-2005. We observe a steady decline from 1977 to 1999 , followed by a modest increase in the years 2001-2005. (From the mid-1990s to the mid-2000s, we are also able to track entrance scores at some other universities. Over this period, it appears that the entry standards for Bachelor of Education courses have risen in NSW and ACT universities, but fallen in Queensland universities.)

\section{Trends in Teacher Pay}

There are three plausible ways in which changing salaries for teachers and non-teachers might have caused the decline in the academic aptitude of new teachers. ${ }^{14}$ First, it might be the case that returns to aptitude in teaching have changed over time. For example, if returns to aptitude fell for teaching, we would expect this to lower the mean aptitude in teaching (so long as an individual's aptitude in teaching and nonteaching occupations is positively correlated). A second possible hypothesis is that the there has been a fall in the salary of new teachers, relative to new workers in other occupations. All else being equal, a fall in teacher pay should lower the average aptitude of the teaching workforce. Third, pay dispersion in nonteaching occupations may have affected teacher quality. For an individual with the potential to earn a wage at the 90th percentile of the nonteaching distribution, what matters is not only shifts in average pay, but also changes in pay dispersion. If pay dispersion widened in nonteaching occupations, while staying constant in teaching, then we would expect this to disproportionately pull high-ability men and women out of teaching.

\subsection{Returns to Aptitude in Teaching}

The returns to aptitude hypothesis suggests that in a simple model of occupational choice (for example, Roy 1951), in which workers 
Figure 5 Average Earnings of Women in Non-Teaching Occupations by Achievement Decile

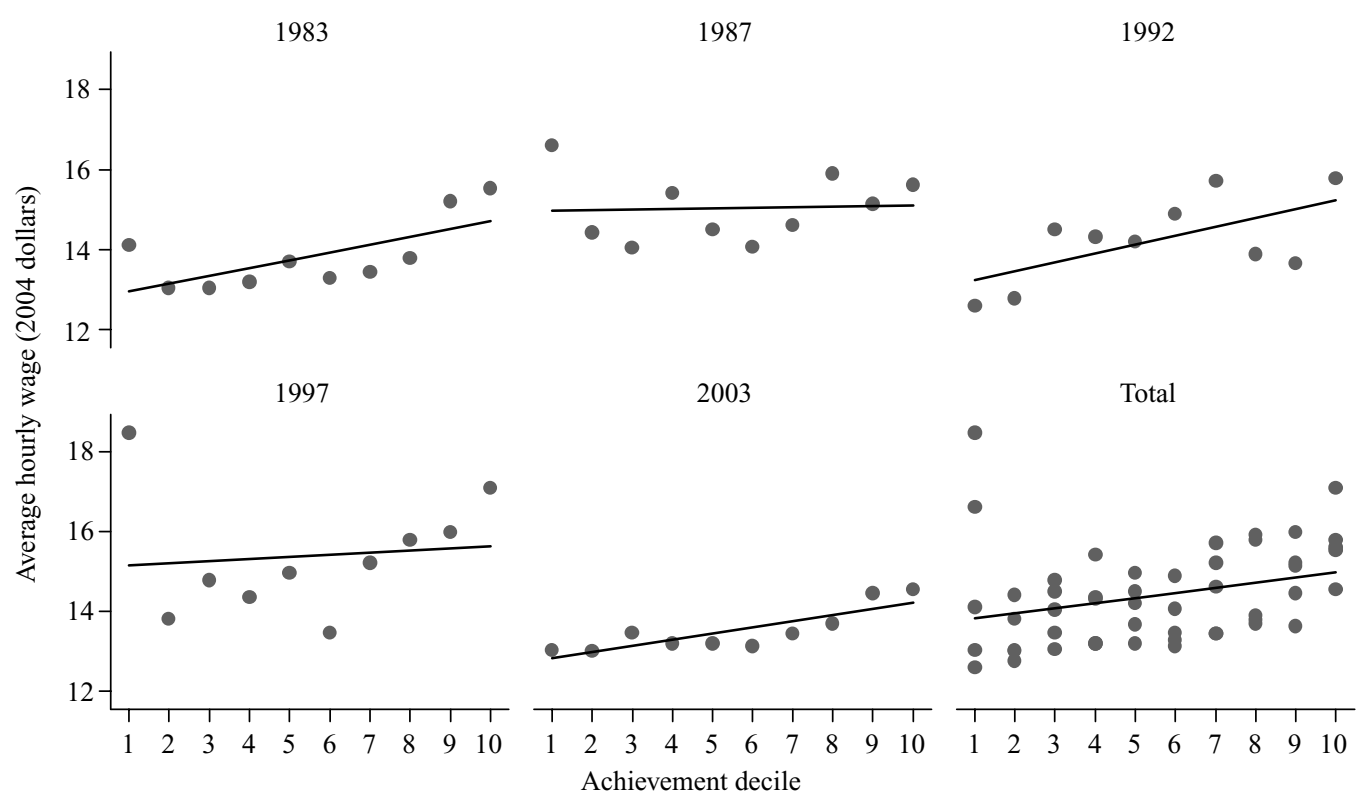

Source: Longitudinal Surveys of Australian Youth.

choose between two sectors with the same average wage, high ability workers will prefer the sector with larger returns to aptitude, while low-ability workers will prefer the sector with smaller returns to aptitude. All else being equal, a fall in the returns to aptitude will reduce the mean ability in a given sector.

In order to estimate returns to aptitude, we need a dataset that provides both aptitude and earnings data. For this purpose, we are restricted to using the LSAY, but do so with the caveat that wages are less precisely measured in the LSAY than in other surveys (for testing other theories, we will use alternative sources of wage data). To begin, we estimate the relationship between aptitude and earnings for all workers in non-teaching occupations. As Marks and Fleming (1998) have shown for earlier LSAY cohorts, individuals who scored in higher achievement deciles tend to earn higher wages. We replicate their findings, restricting the sample to non-teachers. The fitted regression lines show a positive relationship between academic aptitude and earnings for women (Figure 5) and men (Figure 6). With the exception of women in 1987, moving up one achieve- ment decile boosts hourly wages in each of the groups by $\$ 0.15-0.30$ (as we show below, these effects are larger if we restrict the sample only to professionals or university graduates). We do not observe any systematic differences in the return to aptitude between men and women, or between earlier and later cohorts.

Next, we look at the returns to aptitude among female teachers (Figure 7) and male teachers (Figure 8). In both cases, we find little evidence that those in higher aptitude groups systematically receive higher wages. (Though in the case of male teachers, it is possible that this is simply due to the small sample size.)

As a further test of the returns to aptitude, we regress hourly wages on each individual's achievement percentile for all employees, those with a university degree, those in professional occupations and teachers. In each case, the regressions include cohort fixed effects, so that we are identifying the relationship between pay and aptitude only within cohorts. ${ }^{15}$ The results are presented in Table 1. Among all non-teachers, non-teachers with a degree and non-teaching professionals, we observe 
Figure 6 Average Earnings of Men in Non-Teaching Occupations by Achievement Decile

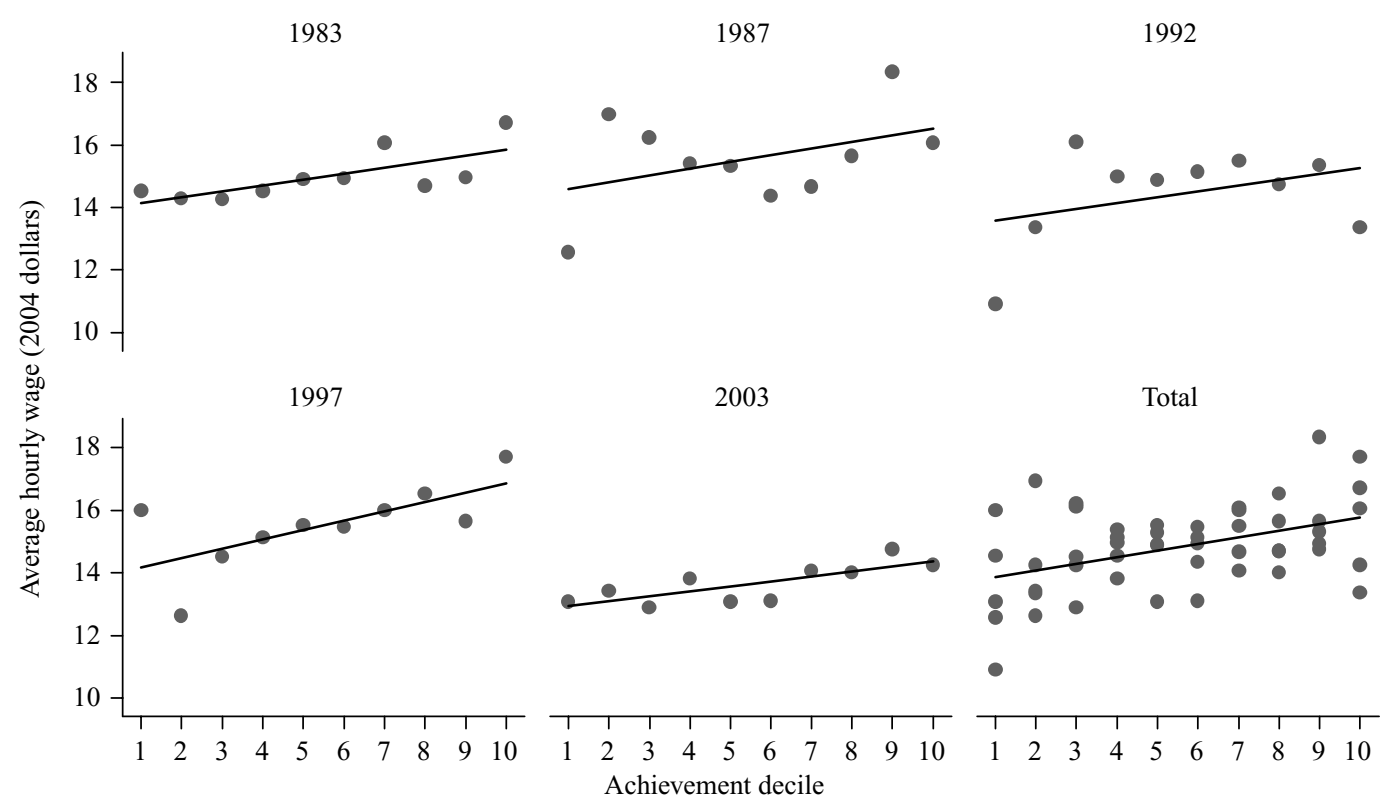

Source: Longitudinal Surveys of Australian Youth.

Figure 7 Average Earnings of Female Teachers by Achievement Decile

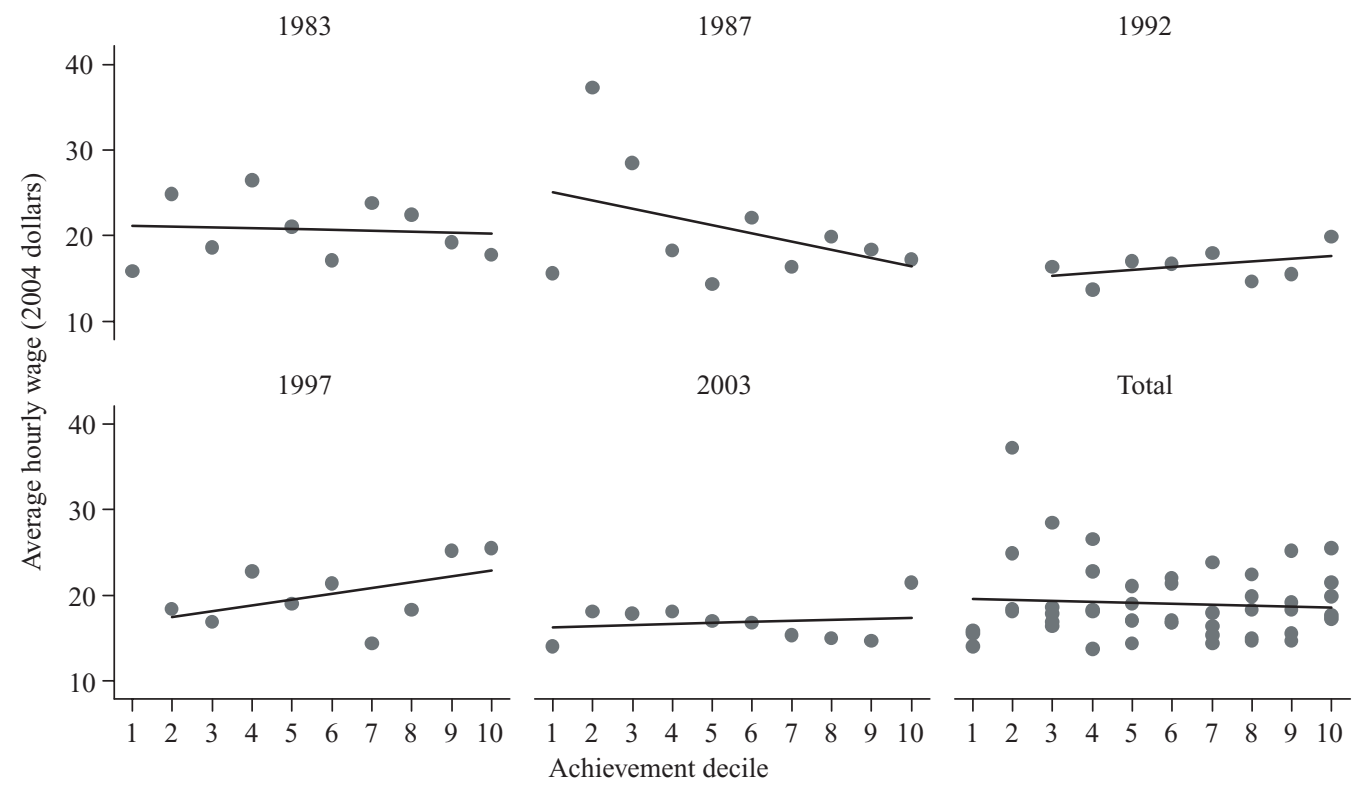

Source: Longitudinal Surveys of Australian Youth.

positive and statistically significant returns to aptitude. However, among teachers, the coefficient on aptitude is negative and statistically insignificant.
It is important to note that the findings above differ from those of Hoxby and Leigh (2004) for the United States. They observed that the return to aptitude (measured by college

\footnotetext{
(C) 2008 The University of Melbourne, Melbourne Institute of Applied Economic and Social Research
} 
Figure 8 Average Earnings of Male Teachers by Achievement Decile

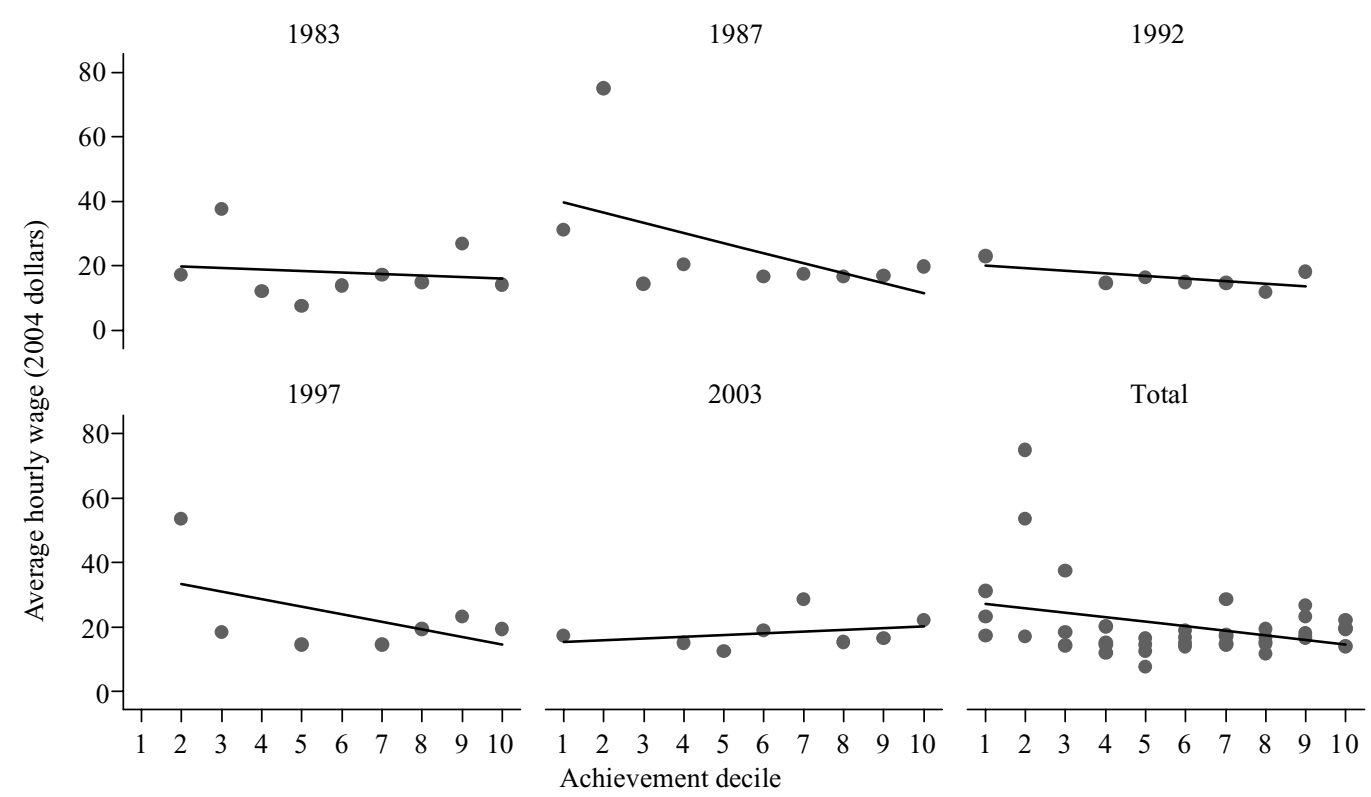

Source: Longitudinal Surveys of Australian Youth.

Table 1 Returns to Aptitude in Non-Teaching and Teaching (dependent variable: hourly wage, 2004 dollars)

\begin{tabular}{lcccc}
\hline & All non-teachers & $\begin{array}{c}\text { Non-teachers } \\
\text { with degree }\end{array}$ & $\begin{array}{c}\text { Non-teaching } \\
\text { professionals }\end{array}$ & Teachers \\
\hline Panel A: Women & & & & \\
Achievement percentile/10 & $0.204^{* * *}$ & $0.335^{* *}$ & $0.281^{* *}$ & -1.331 \\
& {$[0.045]$} & {$[0.155]$} & {$[0.132]$} & {$[1.136]$} \\
Cohort fixed effects & Yes & Yes & Yes & Yes \\
Respondents & 7038 & 1272 & 1557 & 525 \\
$R^{2}$ & 0.01 & 0.02 & 0.01 & 0.00 \\
Panel B: Men & & & & \\
Achievement percentile/10 & $0.211^{* * *}$ & $0.579^{* *}$ & $0.579^{* *}$ & -0.870 \\
& {$[0.060]$} & {$[0.292]$} & {$[0.230]$} & {$[0.916]$} \\
Cohort fixed effects & Yes & Yes & Yes & Yes \\
Respondents & 6435 & 903 & 1172 & 135 \\
$R^{2}$ & 0.01 & 0.00 & 0.01 & 0.05 \\
\hline
\end{tabular}

Notes: Pooled regressions, estimated from LSAY data. Robust standard errors in brackets. ${ }^{* * *},{ }^{* *}$ and ${ }^{*}$ denote statistical significance at the 1 per cent, 5 per cent and 10 per cent levels, respectively. Where $\mathrm{Y}$ is the hourly wage of individual $i$ in LSAY cohort $t$, and A is the individual's achievement percentile (divided by 10), the regression is $Y_{i t}=\alpha+\beta A_{i t}+I_{t}+\epsilon_{i t}$.

selectivity) was strongly positive for those entering the teaching profession in the 1960s, but approximately zero in the 1990s. By contrast, we do not observe any evidence of returns to aptitude in Australian teaching in the 1980s, 1990s or 2000s.

It is most likely that these results are driven by the widespread use of uniform salary sched- ules in government schools throughout the period in question. These schedules apply to all government school teachers in a given state or territory and typically prescribe the starting salary for new teachers, with little flexibility for more academically gifted teachers to be placed on a higher rung of the schedule. ${ }^{16}$ In contrast, salary schedules were more 
Figure 9 Ratio of Teacher Earnings to Non-Teachers with a Degree

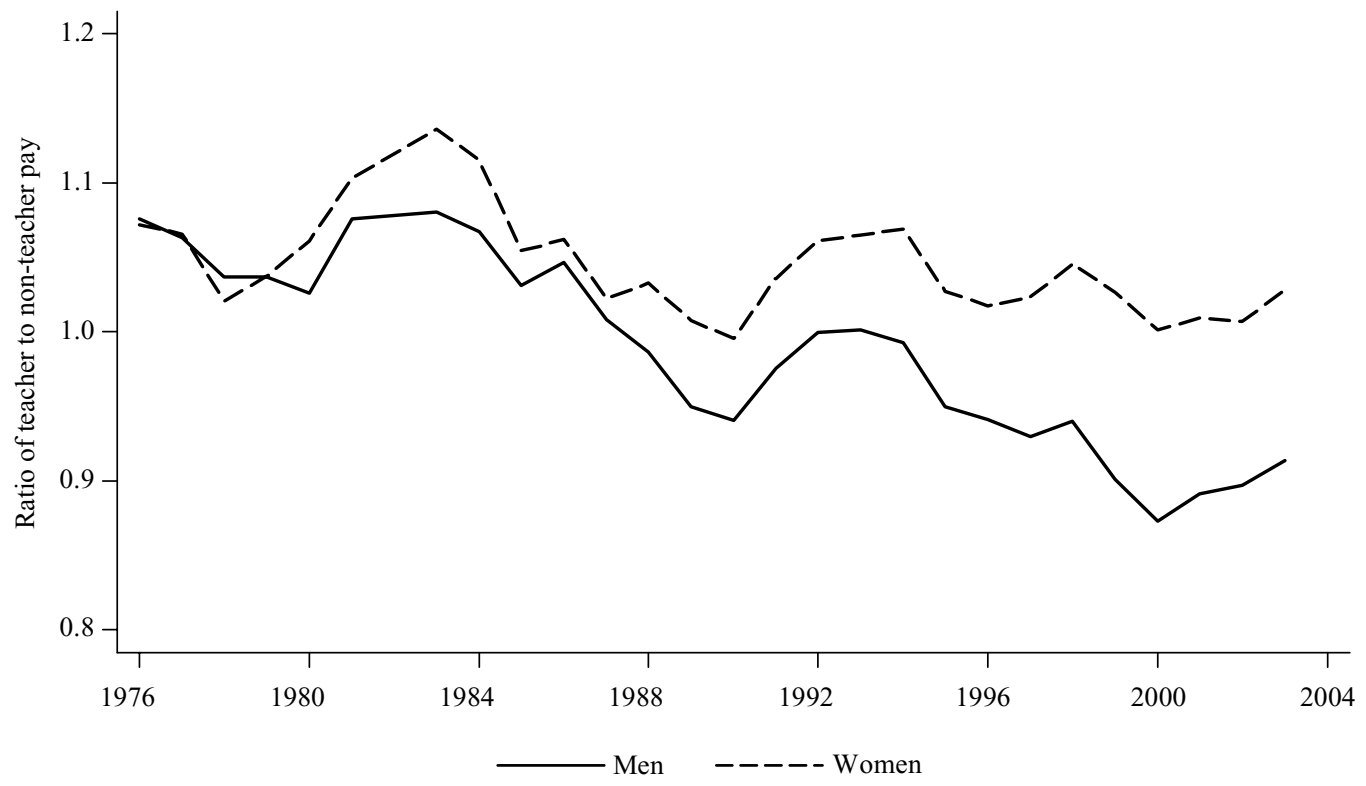

Source: Graduate Destination Survey. Sample is recent university graduates working full-time.

flexible in the United States during the 1960s. Another factor in the move towards uniform salary schedules in the United States was that teacher unions grew much more industrially powerful from the 1960s to the 1990s (Hoxby 1996); in contrast, Australian teacher unions were industrially effective both in the 1980s and 2000s and uniform salary schedules applied across this period.

Given that we do not observe any significant returns to aptitude in the Australian teaching profession throughout the period in question, we do not believe that this factor played a role in the decline in teacher quality that occurred between 1983 and 2003. We therefore turn to our two other factors-average teacher salaries and pay dispersion in non-teaching occupations.

\subsection{Average Teacher Salaries}

To analyse long-run trends in average teacher pay, we use salary data from the Graduate Destination Survey (GDS), a large survey of new graduates covering the period 1976-2003. ${ }^{17}$ For students who finish university in November, the GDS sends out a survey the follow- ing April. Excluding respondents with missing data on occupation or income, the sample size is 9002 in 1976 and 33893 in 2003. Of these, 27 per cent of the sample were working as teachers in 1976, and 14 per cent in 2003. ${ }^{18}$ The GDS allows us to compare the salaries of new teachers with the salaries of other university graduates. Because the GDS has a much larger sample than the LSAY, we are able to observe more precisely the earnings of teachers and non-teachers. The GDS data are described in more detail in Leigh and Ryan (2006, Appendix I).

Figure 9 shows the ratio of teacher earnings to the earnings of non-teachers with a degree. For women, the ratio rose from 1978-1983, but fell during the 1980s. Since 1990, female teacher pay has kept pace with the earnings of women with a degree. For men, teacher pay steadily declined throughout the 1980 s and 1990s.

Since our focus in Section 3 was on changes between 1983 and 2003, it is useful to compare over this period the earnings of new teachers with non-teachers who have an undergraduate degree. For women, teacher pay fell from 
114 per cent to 103 per cent of non-teacher pay between 1983 and 2003. For men, teacher pay fell from 108 per cent to 91 per cent of nonteacher pay. ${ }^{19}$ In the United States, researchers have argued that one of the reasons for the decline in teacher quality was that gender pay discrimination fell rapidly in non-teaching occupations, but did not change very much in teaching. In Australia, our trends for women and men suggest that this was not as important a factor; at least during the 1980s and 1990s.

In Leigh and Ryan (2006, Appendix III) we analyse trends in average teacher pay in more detail, using the Australian Bureau of Statistics' Employee Earnings and Hours surveys, and taking account of shifts in the age composition of teachers and non-teachers by using microdata from the quinquennial censuses. This analysis supports the trends shown in Figure 9 in three respects: (i) teacher pay kept pace with non-teacher pay in the late-1970s and early 1980s; (ii) teacher pay fell behind non-teacher pay over the period 1983-2003; and (iii) the relative decline in teacher pay was sharper for men than for women.

\subsection{Pay Dispersion in Non-Teaching Occupations}

A third factor that might have affected the decision to enter teaching is a change in pay differentials in non-teaching occupations. As a simple Roy-type model suggests, rising pay dispersion in non-teaching occupations might have disproportionately attracted high-ability university graduates away from teaching and into alternative occupations.

To measure salaries, we again use the GDS. However, since we do not observe ability in the GDS, we need to make the assumption that ability and wages are positively correlated in non-teaching occupations. In this, we rely on the results shown in Table 1, which indicate a strong positive correlation between wages and ability for men and women in non-teaching occupations.

Figure 10 shows the ratio of earnings at the 90th percentile to earnings at the 10th percentile in non-teaching occupations over the period 1976 to 2003. Over this period, the pay gap in non-teaching occupations steadily

Figure 10 Ratio of Pay at the 90th and 10th Percentiles (Non-Teaching Occupations)

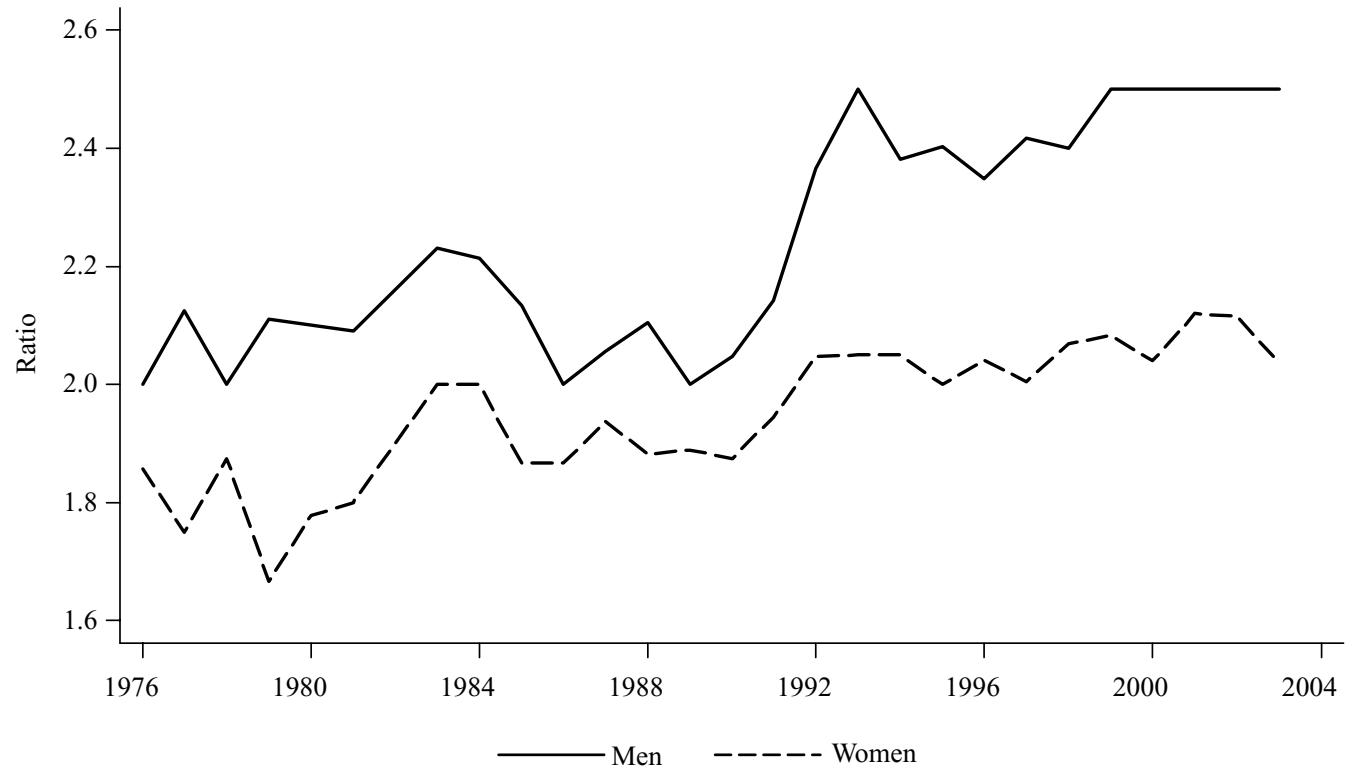

Source: Graduate Destination Survey. Sample is recent university graduates working full-time. 
Figure 11 Ratio of Pay at the 90th and 10th Percentiles (Teaching)

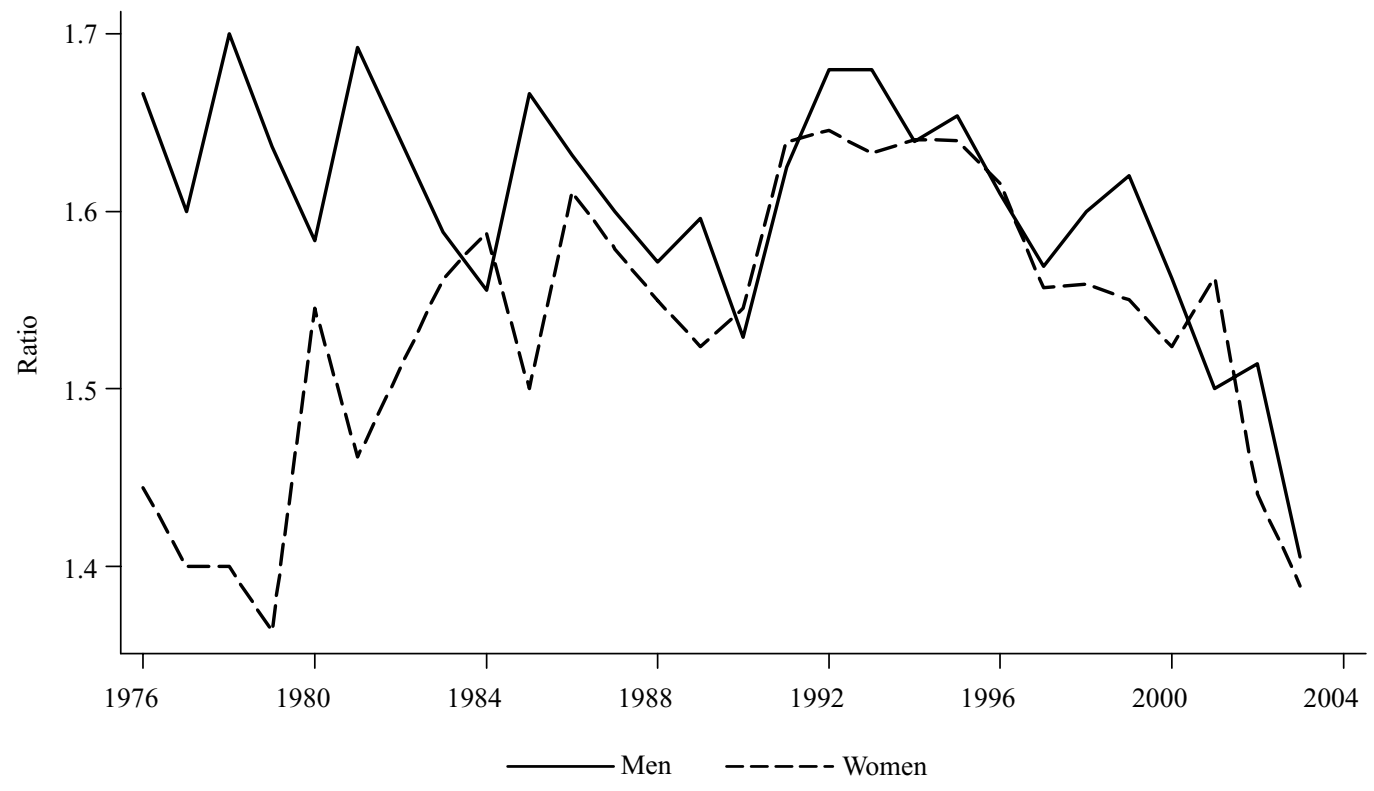

Source: Graduate Destination Survey. Sample is recent university graduates working full-time as teachers.

widened. For men, the 90/10 ratio increased from 2 to 2.5 , while for women, the $90 / 10$ ratio in non-teaching occupations rose from 1.8 to 2. (For the 90/50 ratio, the pattern is similar. For men, the 90/50 ratio in non-teaching occupations rose from approximately 1.55 to 1.7 . For women, the $90 / 50$ ratio rose from approximately 1.4 to 1.5 .)

As we have shown above, the returns to aptitude in teaching occupations did not rise over this period (they were always approximately zero). Consistent with this, there was no rise in pay dispersion within teaching. Figure 11 shows the 90/10 ratio within teaching. Given the smaller samples, this measure is more volatile than those for all recent university graduates, but it is clear that, in contrast to non-teaching occupations, there is no long-run increase in pay dispersion within the teaching profession between the mid-1970s and mid-2000s. (The same is true if one looks at the 90/50 pay ratio within teaching.)

Given that pay dispersion rose in nonteaching occupations, but not in teaching, we would expect this to have disproportionately attracted high-ability men and women into non- teaching occupations. As we will show below, it is plausible that these changes in pay dispersion in non-teaching occupations are as important to explaining the decline in teacher aptitude as are changes in average pay.

\section{A Model of Occupational Choice}

We turn now to understanding why the academic aptitude of new teachers might have declined. In this section, we set out a formal model of the decision to enter teaching using a simple career choice model, akin to that in Hoxby and Leigh (2004). In Section 6, we apply the model to the data.

Assume all individuals enter teaching or an alternative non-teaching career, and that the alternate occupation also requires a university degree, thus making it possible to ignore the costs of university education. Assume further that in making the occupational choice, students' decisions are not influenced by the possibility of later switching into a different career.

The probability that an individual of ability $i$, gender $s$, in year $t$ chooses a teaching career (denoted by the superscript $t c h r$ ) instead of an 
alternative non-teaching career (denoted by the superscript alt), will therefore be determined by the individual's expected pay in teaching and in an alternative occupation: ${ }^{20}$

$P(t c h r)_{i s t}=F\left[E\left(w_{i t}^{\text {s.tchr }}\right), E\left(w_{i t}^{\text {s.alt }}\right)\right]$

Next, we take logs and add an aptitude group fixed effect, a gender fixed effect, a year fixed effect and a normally distributed error term, $\epsilon$ :

$$
\begin{aligned}
P(t c h r)_{i s t}= & \beta_{0}+\beta_{1} \operatorname{Ln}\left(w_{i t}^{\text {s.tchr }}\right) \\
& +\beta_{2} \operatorname{Ln}\left(w_{i t}^{\text {s.alt }}\right)+I_{i}^{\text {apt }}+I_{s}^{\text {sex }} \\
& +I_{t}^{\text {year }}+\varepsilon_{i s t}
\end{aligned}
$$

From the results above, we see that there were no statistically significant returns to aptitude in teaching in the years covered by our analysis. We can therefore replace $\operatorname{Ln}\left(w_{i \mathrm{t}}^{\text {s.tchr }}\right)$ with $\operatorname{Ln}\left(\bar{w}_{t}^{\text {s.tchr }}\right)$ and estimate the equation:

$$
\begin{aligned}
P(t c h r)_{i s t}= & \beta_{0}+\beta_{1} \operatorname{Ln}\left(\bar{w}_{t}^{\text {s.tchr }}\right) \\
& +\beta_{2} \operatorname{Ln}\left(w_{i t}^{\text {s.alt }}\right)+I_{i}^{\text {apt }}+I_{s}^{\text {sex }} \\
& +I_{t}^{\text {year }}+\varepsilon_{i s t}
\end{aligned}
$$

where the coefficient on $\beta_{1}$ represents the effect of average teacher pay and the coefficient on $\beta_{2}$ represents the effect of wages for that aptitude group in alternative (non-teaching) occu- pations. The fixed effects reflect the possibility that there may be unobserved factors specific to an aptitude group, gender, or year that affect the probability of becoming a teacher.

We should expect the probability of entering teaching to be positively correlated with average teacher pay (that is, $\beta_{1}>0$ ) and negatively correlated with the wage in alternative occupations (that is, $\beta_{2}<0$ ).

\section{Econometric Analysis}

We now use the model to formally analyse the changes in teacher quality, as measured by teachers' academic aptitude. Given the limitations of the wage data in the LSAY, we instead impute earnings using the GDS. From the GDS, we can calculate real earnings for teachers and non-teachers, which we impute based upon the year in which a typical LSAY respondent was observed in the labour force.

For teachers, we assign all respondents the average teaching wage for their gender and year. For non-teachers, wages are assigned according to gender, year and ability. To impute ability group wages, we divide LSAY respondents into five ability quintiles and assign to

\begin{tabular}{|c|c|c|c|c|c|}
\hline Achievement quintile & Bottom & 2 & 3 & 4 & Top \\
\hline \multicolumn{6}{|l|}{ Panel A: Women } \\
\hline (1) $\Delta \operatorname{Ln}\left(\bar{w}_{t}^{f . t c h r}\right)$ & -0.040 (for all) & & & & \\
\hline (2) $\Delta \operatorname{Ln}\left(w_{i \mathrm{t}}^{\text {f.alt }}\right)$ & 0.043 & 0.072 & 0.076 & 0.164 & 0.267 \\
\hline (3) Share who are teachers 1983 & 0.032 & 0.023 & 0.072 & 0.120 & 0.108 \\
\hline (4) Share who are teachers 2003 & 0.026 & 0.065 & 0.090 & 0.065 & 0.058 \\
\hline (5) Share who are studying teacher education 1983 & 0.012 & 0.032 & 0.065 & 0.126 & 0.108 \\
\hline (6) Share who are studying teacher education 2003 & 0.022 & 0.056 & 0.069 & 0.070 & 0.054 \\
\hline \multicolumn{6}{|l|}{ Panel B: Men } \\
\hline (7) $\Delta \operatorname{Ln}\left(\bar{w}_{t}^{m . t c h r}\right)$ & -0.126 (for all) & & & & \\
\hline (8) $\Delta \operatorname{Ln}\left(w_{i \mathrm{t}}^{\text {m.alt }}\right)$ & -0.037 & 0.007 & -0.035 & -0.027 & 0.077 \\
\hline (9) Share who are teachers 1983 & 0.005 & 0.015 & 0.020 & 0.020 & 0.045 \\
\hline (10) Share who are teachers 2003 & 0.004 & 0.007 & 0.013 & 0.023 & 0.027 \\
\hline (11) Share who are studying teacher education 1983 & 0.003 & 0.011 & 0.024 & 0.014 & 0.076 \\
\hline (12) Share who are studying teacher education 2003 & 0.005 & 0.011 & 0.019 & 0.020 & 0.016 \\
\hline
\end{tabular}
these groups GDS wages at the 10th, 30th, 50th, 70th and 90th percentiles respectively.

Table 2 shows the changes in our key dependent and independent variables between the

Table 2 Changes in Dependent and Independent Variables

Notes: Pay data (rows 1-2 and 7-8) are for new university graduates, from the GDS. Occupational choice data (rows 3-6 and 9-12) are from the LSAY, for teacher education students and new teachers. 
first and last LSAY cohort. The first row shows that the average real salary of a starting female teacher fell by 4 per cent over this period. By contrast, real wages in alternative occupations grew, by 4 per cent for the bottom aptitude group, and by 27 per cent for the top aptitude group. Rows 3 to 6 show the same declines in teacher aptitude discussed in Section 3.

For men, row 7 shows that the average real salary of a starting male teacher fell by 13 per cent. Row 8 shows that-just as for women-average male pay rose more substantially at the top of the distribution than at the bottom. Rows 9 to 12 show changes in teacher aptitude for men.

We now turn to estimating equation (3). Given our available data, there are a number of important limitations in our approach. First, as we have already noted, we do not estimate the effect of returns to aptitude in teaching, since we observe no consistent returns to aptitude in any years that we analyse. Second, unlike the analysis of Hoxby and Leigh (2004) for the United States, we use variation between men and women in place of cross-state variation. To the extent that the career choice decisions of men and women interact with one another, this may affect our estimated coefficients. Third, since we do not attempt to instrument for our pay variables, there remains the possibility that our variation in salary is in fact endogenous with respect to the quality of those entering teacher education.

Table 3 shows the results from estimating our career choice equations. ${ }^{21}$ In the first column, we find that average teacher pay is positively correlated with whether a woman enters teaching, while the pay in alternative occupations is negatively correlated with the decision to become a teacher. In the second column, the dependent variable is the decision to study teacher education and we again find that average teacher pay is positively correlated with the share studying teaching, while pay in alternative occupations is negatively related to entry into teacher training courses. However, only the coefficients on alternative occupation salaries are statistically significant.

With the caveat that our coefficients for average teacher salary are not significant, it is
Table 3 Estimating the Effect of Salary on Career Choice

\begin{tabular}{lcc}
\hline & $\begin{array}{c}(1) \\
\text { Dependent } \\
\text { variable is } \\
\text { share who }\end{array}$ & $\begin{array}{c}(2) \\
\text { Dependent } \\
\text { variable is } \\
\text { share who study } \\
\text { become teachers }\end{array}$ \\
\hline teacher education \\
\hline $\operatorname{Ln}\left(\bar{w}_{t}^{\text {s.tchr }}\right)$ & 0.022 & 0.099 \\
& {$[0.177]$} & {$[0.151]$} \\
$L n\left(w_{i t}^{\text {s.alt }}\right)$ & $-0.170^{* * *}$ & $-0.178^{* * *}$ \\
Aptitude group, & {$[0.062]$} & {$[0.060]$} \\
gender and & & \\
year fixed effects & Yes & Yes \\
Observations & 50 & 50 \\
$R^{2}$ & 0.73 & 0.74 \\
\hline
\end{tabular}

Notes: Pooled regressions, estimated from LSAY occupational choice data and GDS data, collapsed to aptitude $\times$ sex $\times$ cohort cells. Robust standard errors in brackets. ${ }^{* * *},{ }^{* *}$ and ${ }^{*}$ denote statistical significance at the 1 per cent, 5 per cent and 10 per cent levels, respectively.

possible to now combine the estimates from Tables 2 and 3 to see the effects of pay changes on teacher aptitude. For example, the share of women in the top aptitude group working as teachers fell by approximately 5 percentage points between 1983 and 2003. Our results suggest that this was due in part to falling mean teacher salaries $(-0.04 \times 0.022=-0.0009)$, but mostly to rising wages in alternative occupations $(0.267 \times-0.170=-0.045)$. To take another example, the fraction of top-quintile men studying teacher education fell by 6 percentage points between 1983 and 2003. Our results suggest that this was due about equally falling mean teacher salaries $(-0.126 \times 0.099=-0.013)$ and rising wages in alternative occupations $(0.077 \times-0.178=-0.014)$.

Overall, our econometric results and the changes in the independent variables suggest three conclusions. First, the fall in mean salaries mattered more for men than for women. Second, rising returns to aptitude in non-teaching occupations mattered more for women than for men. And third, mean salaries affected the decision to study teacher education more than they affected the decision to become a teacher. 


\section{Conclusion}

Using data from a variety of sources, we estimate the changes in teacher quality over the past quarter century. We observe a substantial decline in the academic aptitude of the typical teacher over this period. Between 1983 and 2003 , the average percentile rank of those entering teacher education fell from 74 to 61 , while the average rank of new teachers fell from 70 to 62 .

What caused this change? We are able to reject one hypothesis - that the returns to aptitude in teaching declined. Looking across cohorts, we find no evidence that more academically talented individuals have ever been paid more in teaching. This is perhaps because teacher unions in Australia have consistently rejected merit pay and have remained industrially powerful throughout the period in question.

Our econometric analysis focuses on two remaining explanations for the decline in teacher quality. The first is average pay. Over the period 1983-2003, the average salary of a starting teacher fell both in real terms and relative to non-teachers. In real terms, teacher salaries declined by 4 per cent for women and by 13 per cent for men. Relative to university graduates entering other occupations, starting teacher pay fell by 11 per cent for women and by 17 per cent for men.

The 1980s and 1990s also saw changes in the returns to aptitude in non-teaching occupations. Between 1983 and 2003, the real wages of top quintile female university graduates entering non-teaching occupations rose by 27 per cent, while the real wages of top quintile male university graduates entering non-teaching occupations rose by 8 per cent. For both men and women, real wages at the bottom quintile grew more slowly. As non-teaching occupations became more attractive for high-ability university graduates, fewer were inclined to choose teaching.

We believe that both these factors-falling average pay for teachers and rising returns to aptitude in non-teaching occupations-are responsible for the declining academic aptitude of new entrants to the teaching profession. We find some evidence that average pay has been more important in the decline of male teacher quality, while returns to aptitude in alternative occupations mattered more for the decline in female teacher quality.

Lastly, it is important to emphasise that our study focuses on the reasons for the decline in the academic aptitude of teachers over the past quarter century. Reversing these factors is not the only way of raising teacher aptitude. For example, while boosting average teacher pay may be one way of encouraging more able people to enter teaching, it is also possible that increasing the returns to aptitude in teaching may be a more cost-effective way of raising the quality of the teaching profession. ${ }^{22}$

First version received May 2007;

final version accepted September 2007 (Eds).

\section{Endnotes}

1. Australian Bureau of Statistics, Schools, Australia, 2004, Cat. no. 4221.0, Table 64. Figures are from the August 2004 survey. The number of full-time equivalent teachers is 233065 .

2. One way of thinking about the magnitude of this large hypothetical increase in teacher quality is to compare it with a very large class size cut. An oft-cited upper bound estimate of the impact of reducing class sizes is Krueger (1999), who finds that a one-sixth reduction in class sizes raises the test score of the median student to the 54th percentile. (Though compare Hoxby 2000 and Hanushek 1998, who find zero or negligible benefits of across the board class size reductions.)

3. This change compares teachers in the Project Talent dataset (observed as teachers in the early 1970s) with those in the National Education Longitudinal Study of 1988 (observed as teachers in 2000). Corcoran, Evans and Schwab (2004a, 2004b). also present results for the Wisconsin Longitudinal Study (observed as teachers in 1964). In the WLS, the average teacher was at the 60th percentile.

4. There are several differences between our study and that of Leigh (2006): it looks only at teacher education students, while we look at both teachers and teacher education students; it looks at the period 1989-2003, we also look at teacher pay in the 1970s and 1980s; it uses within university test score rankings as a measure of aptitude, while we use LSAY tests; and it uses cross-state variation, while we primarily exploit changes over time.

5. For the United States, several studies have analysed the effect of teacher pay on student achievement. Card and Krueger (1992) find that a 10 per cent rise in teachers' salaries leads to a 0.1 percentage point increase

\footnotetext{
C 2008 The University of Melbourne, Melbourne Institute of Applied Economic and Social Research
} 
in the rate of return to schooling for white males born between 1920 and 1949, while Loeb and Page (2000) find that a 10 per cent increase in the teaching wage reduces the high school dropout rate a decade later by 3-4 per cent. But using more recent cohorts, Betts (1995) and Grogger (1996) find only a weak or non-existent relationship between pay and student performance. In a meta-analysis of 119 studies, Hanushek (1997) notes that 45 per cent observe a positive relationship between teacher pay and student performance, 25 per cent find a negative relationship and the remainder did not specify the sign of the effect.

6. In the United Kingdom, Zabalza (1979) and Chung, Dolton and Tremayne (2004) find a positive relationship between teacher pay and the supply of teachers. Other literature looks at the decision to quit teaching and generally finds a robust relationship between pay and retention. For the United States, see Hanushek, Kain and Rivkin (1999); for the United Kingdom, see Dolton and van der Klaauw (1999), but compare Frijters, Shields, and Wheatley-Price (2004). In the Australian context, Webster, Wooden and Marks (2006) cite a survey by Ministerial Council on Education, Employment, Training and Youth Affairs, which found that the most frequently mentioned factor that would assist retention was remuneration, rating above reduced workloads and improved employment conditions. For an analysis of factors affecting teacher supply and demand in Australia, see Preston (1997). For a discussion of trends in Australian teacher salaries until the mid-1990s, see Crowley (1998).

7. There is considerable debate in the literature as to how best to measure teachers' classroom performance. Among the possible approaches are teacher fixed effects regressions, assessments by principals and ratings from independent observers.

8. We know of no Australian evidence on this point. However, using data from the 1958 British National Child Development Survey, Nickell and Quintini (2002) found a high correlation (0.63-0.65) between aptitude tests administered at age 16 and age 37 .

9. A meta-analysis by Hanushek (1997) found that in 64 per cent of studies looking at the relationship between teacher test scores and student outcomes, the relationship was positive, while the relationship was negative in only 25 per cent of studies (in the remaining 11 per cent of studies, the sign was unspecified).

10. For the five cohorts used to analyse commencing teacher trends, the proportion of the original cohorts who remained in the sample in the required years were 56,39 , 36,48 and 45 per cent respectively. The minimum responding sample size from any cohort was 1961 observations. The response rates for the cohorts used to analyse trends in those studying teacher education were 48, 37, 65, 64 and 55 per cent respectively. The minimum responding sample size from any cohort was 2039 observations.

11. In YIT 65 and YIT 70, respondents were tested at age 10. Nonetheless, results from these tests appear to be comparable with those from tests carried out at age 14. For example, Marks et al. (2000) show that the relationship between childhood test scores and year 12 completion, and between childhood test scores and university participation, is similar for both sets of tests.

12. There is a high degree of overlap between 14 year olds and those in grade 9. Rothman (2002) shows that when the sample frame was 14 year olds, the majority were in grade 9; and when the sample frame was grade 9 students, the majority were aged 14 .

13. Note that our approach compares the academic ability of teachers with those in their cohort and hence ignores changes in the average academic ability of the entire cohort. If the average academic ability of those taking the test had risen over time, this might mitigate our findings somewhat. However, this does not appear to have occurred. For example, Rothman (2002) finds no statistically significant change in mean literacy and numeracy scores if one compares 14 year olds across the 1975-1998 tests, and a slight decline if one compares 14 year olds in year 9 across the 1975-1998 tests. See also Leigh and Ryan (2008).

14. Although our analysis focuses only on salary, we cannot rule out the possibility that changing non-wage characteristics in teaching (or alternative occupations) have also affected teacher quality. However, it is worth noting that one of the most important non-wage characteristics of teaching is the student-teacher ratio, which has fallen steadily over time. For example, the average teacherstudent ratio was 18.6 in 1976, 16.1 in 1983, 15.3 in 1993 and 14.5 in 2003 (Australian Bureau of Statistics, various years).

15. The cohort fixed effects in Table 1 are jointly significant (at the 10 per cent level or better) in all except two specifications: male non-teaching professionals and male teachers.

16. Government school salary schedules also indirectly affect the salary structure in non-government schools, since they are often used as the starting point in non-government schools' pay negotiations.

17. It is unclear precisely what year the GDS began covering Colleges of Advanced Education (at which many teachers did their training). According to Graduate Careers Australia, which administers the survey, the GDS included some CAEs in the mid-1970s, and all CAEs were in the GDS by about 1980 .

18. A number of past studies have analysed trends in Australian teacher pay over shorter periods. Crowley (1998) presented data on trends in the pay of new teachers relative to other new university graduates, but did not disaggregate the data by gender. Zappala and Lombard (1991) compared the pay of new and experienced NSW teachers with average weekly earnings, but did not account for shifts in the age composition of the workforce, nor did they look separately at men and women. Both studies observed a decline in the relative pay of teachers during the 1980s and 1990s. 
19. Given the widespread use of uniform salary schedules, it is not obvious to us why the relative pay of male teachers should have fallen more than the relative pay of female teachers (since the same patterns is observed when looking at real pay trends, we can rule out differences in the denominator as a factor). One possibility is that salaries in high schools (where most men teach) had previously been substantially higher than salaries in primary schools (where most women teach), and that this gap narrowed during the 1980s and 1990s.

20. In a cross-state analysis, Leigh (2006) also includes student-teacher ratios as a proxy for non-wage characteristics. Since we do not have these data by gender, we do not include them in our regressions.

21. We also tested whether the fixed effects in Table 3 were jointly significant at the 10 per cent level or better. The aptitude group fixed effects were significant in both specifications, while the cohort fixed effects were not significant in either specification. The female coefficient was significant in column (2), but not in column (1).

22. For a proposal of this type in the Australian context, see Webster, Wooden and Marks (2005).

\section{References}

Australian Bureau of Statistics (various years), Schools, Australia, Cat. no. 4221.0, ABS, Canberra.

Bacolod, M. P. 2003, 'The role of alternative opportunities in the female labor market in teacher supply and quality: 1940-1990', mimeo, Department of Economics, UCLA.

Ballou, D. and Podgursky, M. 1995, 'Recruiting smarter teachers', Journal of Human Resources, vol. 30, pp. 326-38.

Ballou, D. and Podgursky, M. 1997, Teacher Pay and Teacher Quality, Upjohn, Kalamazoo, Michigan.

Betts, J. 1995, 'Does school quality matter? Evidence from the National Longitudinal Survey of Youth', Review of Economics and Statistics, vol. 77, pp. 231-47.

Card, D. and Krueger, A. B. 1992, 'Does school quality matter? Returns to education and the characteristics of public schools in the United States', Journal of Political Economy, vol. 100, pp. 1-40.

Chung, T.-P., Dolton, P. and Tremayne, A. 2004, 'The determinants of teacher supply: Time series evidence for the UK, 19622001', mimeo, Centre for Economic Performance, London School of Economics.
Committee for the Review of Teaching and Teacher Education 2003, Australia's Teachers: Australia's Future-Background Data and Analysis, Department of Education, Science and Training, Canberra.

Corcoran, S. P., Evans, W. N. and Schwab, R. M. 2004a, 'Changing labor market opportunities for women and the quality of teachers, 1957-2000', American Economic Review, vol. 94, no. 2, pp. 230-5.

Corcoran, S. P., Evans, W. N. and Schwab, R. S. 2004b, 'Women, the labor market, and the declining relative quality of teachers', Journal of Policy Analysis and Management, vol. 23, pp. 449-70.

Crowley, R. (Chair) 1998, A Class Act: Inquiry into the Status of the Teaching Profession, Senate Employment, Education and Training References Committee, Canberra.

Dolton, P. and van der Klaauw, W. 1999, 'The turnover of teachers: A competing risks explanation', Review of Economics and Statistics, vol. 81, pp. 5431-50.

Ehrenberg, R. G. and Brewer, D. J. 1994, 'Do school and teacher characteristics matter? Evidence from high school and beyond', Economics of Education Review, vol. 13, pp. 1-17.

Ferguson, R. F. 1991, 'Paying for public education: New evidence on how and why money matters', Harvard Journal on Legislation, vol. 28, pp. 465-98.

Ferguson, R. F. and Ladd, H. F. 1996, 'How and why money matters: An analysis of Alabama schools', in Holding Schools Accountable: Performance-Based Reform in Education, eds H. F. Ladd, Brookings Institution, Washington, DC.

Figlio, D. 1997, 'Teacher salaries and teacher quality', Economics Letters, vol. 55, pp. 267-71.

Frijters, P., Shields, M. A. and Wheatley-Price, S. 2004, 'To teach or not to teach? Panel data evidence on the quitting decision', IZA Discussion Paper no. 1164, Bonn.

Grogger, J. 1996, 'School expenditures and post-schooling earnings: Evidence from high school and beyond', Review of Economics and Statistics, vol. 78, pp. 62837. 
Hanushek, E. A. 1997, 'Assessing the effects of school resources on student performance: An update', Educational Evaluation and Policy Analysis, vol. 19, pp. 141-64.

Hanushek, E. A. 1998, 'The evidence on class size', W. Allen Wallis Institute of Political Economy Occasional Paper no. 98-1, University of Rochester.

Hanushek, E. A., Kain, J. F. and Rivkin, S. G. 1999, 'Do higher salaries buy better teachers?', National Bureau of Economic Research Working Paper no. 7082, Cambridge, Massachusetts.

Hanushek, E. A. and Rivkin, S. G. 2006, 'Teacher quality', in Handbook of the Economics of Education, eds E. A. Hanushek and F. Welch, Elsevier, Amsterdam.

Higher Education Division, Department of Employment, Education and Training 1990, Tertiary Entrance Scores, Higher Education Series, Report no. 9, AGPS, Canberra.

Hoxby, C. M. 1996, 'How teachers' unions affect education production', Quarterly Journal of Economics, vol. 111, pp. 671718.

Hoxby, C. M. 2000, 'The effects of class size on student achievement: New evidence from population variation', Quarterly Journal of Economics, vol. 115, pp. 1239-85.

Hoxby, C. M. and Leigh, A. 2004, 'Pulled away or pushed out? Explaining the decline of teacher quality in the United States', American Economic Review, vol. 94, no. 2, pp. 236-40.

Krueger, A. 1999, 'Experimental evidence of education production functions', Quarterly Journal of Economics, vol. 114, pp. 497532.

Leigh, A. 2006, 'Teacher pay and teacher aptitude', mimeo, Australian National University.

Leigh, A. 2007, 'Estimating teacher effectiveness from two-year changes in students' test scores', mimeo, Australian National University.

Leigh, A. and Mead, S. 2005, Lifting Teacher Performance, Policy Report, Progressive Policy Institute, Washington, DC.

Leigh, A. and Ryan, C. 2006, 'How and why has teacher quality changed in Australia?',
Centre for Economic Policy Research Discussion Paper no. 534, Australian National University.

Leigh, A. and Ryan, C. 2008, 'How has school productivity changed in Australia?', mimeo, Australian National University.

Loeb, S. and Page, M. 2000, 'Examining the link between teacher wages and student outcomes: The importance of alternative labor market opportunities and non-pecuniary variation', Review of Economics and Statistics, vol. 82, pp. 393-408.

Marks, G. N. and Fleming, N. 1998, 'Youth earnings in Australia 1980-1994: A comparison of three youth cohorts', LSAY Research Report no. 8, ACER, Melbourne.

Marks, G. N., Fleming, N., Long, M. and McMillan, J. 2000, 'Patterns of participation in year 12 and higher education in Australia: Trends and issues', LSAY Research Report no. 17, ACER, Melbourne.

Murnane, R. J., Singer, J. D., Willett, J. B., Kemple, J. J. and Olsen, R. J. 1991, Who Will Teach?, Harvard University Press, Cambridge.

Nickell, S. and Quintini, G. 2002, 'The consequences of the decline in public sector pay in Britain: A little bit of evidence', Economic Journal, vol. 112, pp. 107-18.

Preston, B. 1997, Teacher Supply and Demand to 2003: Projections, Implications and Issues, Australian Council of Deans of Education, Canberra.

Rivkin, S. G., Hanushek, E. A. and Kain, J. F. 2005, 'Teachers, schools, and academic achievement', Econometrica, vol. 73, pp. 417-58.

Rockoff, J. E. 2004, 'The impact of individual teachers on student achievement: Evidence from panel data', American Economic Review, vol. 94, no. 2, pp. 247-52.

Rothman, S. 2002, 'Achievement in literacy and numeracy by Australian 14-year-olds, 1975-1998', Research Report no. 29, ACER, Melbourne.

Roy, A. D. 1951, 'Some thoughts on the distribution of earnings', Oxford Economic Papers, vol. 3, pp. 135-46.

Watson, L. 2005, Quality Teaching and School Leadership: A Scan of Research Findings, 
National Institute for Quality Teaching and School Leadership, Canberra.

Webster, E., Wooden, M. and Marks, G. 2005, 'Teaching and the teacher labour market: The case for reform', Australian Economic Review, vol. 38, pp. 918.

Webster, E., Wooden, M. and Marks, G. 2006, 'Reforming the labour market for Australian teachers', Australian Journal of Education, vol. 50, pp. 185-202.

Zabalza, A. 1979, 'The determinants of teacher supply', Review of Economic Studies, vol. 46, pp. 131-47.

Zappala, J. and Lombard, M. 1991, 'The decline of Australian educational salaries', Australian Bulletin of Labour, vol. 17, pp. 76-95. 